\title{
Bir Ameliyathanenin İklimlendirilmesi Süresince Hava Akımının Modellenmesi
}

\author{
Yasin Polat ${ }^{1}$, Hüseyin Yağ $1^{2}$, Yıldız Koç3* \\ ${ }^{1}$ Mustafa Kemal Üniversitesi, Fen Bilimleri Enstitüsü, Makine Mühendisliği Anabilim Dalı, Hatay, Türkiye (ORCID: 0000-0002-1255-9990) \\ ${ }^{2}$ İskenderun Teknik Üniversitesi, Mühendislik ve Doğa Bilimleri Fakültesi Makine Mühendisliği Bölümü, Hatay, Türkiye (ORCID: 0000-0002-9777-0698) \\ ${ }^{3}$ İskenderun Teknik Üniversitesi, Mühendislik ve Doğa Bilimleri Fakültesi Makine Mühendisliği Bölümü, Hatay, Türkiye (ORCID: 0000-0002-2219-645X)
}

(İlk Geliş Tarihi 22 Şubat 2019 ve Kabul Tarihi 14 Mart 2019)

(DOI: $10.31590 /$ ejosat.531362)

ATIF/REFERENCE: Polat, Y., Yağlı, H. \& Koç, Y. (2019). Bir Ameliyathanenin İklimlendirilmesi Süresince Hava Akımının Modellenmesi. Avrupa Bilim ve Teknoloji Dergisi, (15), 420-432.

\section{$\ddot{\mathbf{O z}}$}

Günümüz ameliyathanelerinin iklimlendirilmesinde kullanılan klima sistemleriyle; sıcaklık ve nem kontrolünün yapılmasının istenmesinin yanı sıra havada taşınabilen mikroorganizma ve toz miktarının, atık anestezi gazı ve kötü koku oranının önemli ölçüde azaltması da istenmektedir. Ayrıca kullanılan klima sistemleri ile standartlarda belirtilen koruma alanının oluşturabilmesi hedeflenmektedir. Bu sayede ameliyat esnasında kesi yapılan bölgeden hastaya enfeksiyon bulaşma riski de en aza indirgenebilmelidir. Bu nedenle mevcut çalışmada, Türkiye'de mevcut durumda bulunan bir devlet hastanesinin ameliyathanesinin iklimlendirilmesi sonucunda oluşabilecek sıcaklık dağılımları incelenmiștir. Çalışma kapsamında ameliyathanenin incelenmesinde iki farklı model (Model 1 ve Model 2) tasarlanmış ve tasarlanan bu modeller ANSYS Fluent programı ile simüle edilerek sayısal olarak analiz edilmiştir. Model 1 tavandan üfleme, kenarlardan emme menfezleri ile hava emen bir sistem olarak tasarlanırken Model 2 aseptizör cihazı ile iklimlendirme yapacak şekilde tasarlanmıştır. Tasarlanan her bir model için x düzlemi boyunca beş ve z düzlemi boyunca üç farklı kesitte inceleme yapılmıștır. Çalıșma sonucunda, Model 1'de ameliyat lambalarının cerrahi alan üzerinde konumlandırılması sonucu ölü kış bölgelerinin oluştuğu görülmüștür. Ayrıca bu modelde incelenen kesitlerde salondaki sıcaklık değerlerinin personeli ve hastayı rahatsız edici değerler olmadığı görülmüştür. Model 2'de yüksek hava akış hızı nedeniyle ameliyathane personelinin konforsuzluk yaşadığı, cerrahi alan üzerinde laminer akışın sağlanamaması nedeniyle de cerrahi alan enfeksiyonu gelişiminin mümkün olabileceğı görülmüştür. Çalışmanın sonuçları incelendiğinde, standartlara ve literatürdeki çalışmaların sonuçlarına paralel olarak ameliyathanelerde en uygun havalandırma tekniğinin bu çalışmada Model 1 olarak tanımlanan tavandan üfleme ve kenarlardan emme menfezleri ile hava emen iklimlendirme sistemi olduğu görülmüştür.

Anahtar Kelimeler: Ameliyathane, İklimlendirme, Aseptizör, Modelleme, Fluent.

\section{Modelling of Air Flow During Air Conditioning in an Operating Room}

\begin{abstract}
With the air conditioning systems used in the air conditioning of today's operating rooms; it is desirable that the amount of microorganism and powder that can be carried in the air to be significantly reduced as well as the temperature, humidity, waste anaesthesia gas, the odour ratio control. In addition, it is aimed to be able to form the protection area specified in the standards with the air-conditioning systems used. In this way, the risk of infection to the patient from the incision site during the operation should be minimized. Therefore, in the present study, the temperature distribution in an operating room of a state hospital in Turkey were examined. In the study, two different models (Model 1 and Model 2) were designed and the designed models were numerically analysed and simulated by using ANSYS Fluent software. Model 1 is designed as a system that blows air from the ceiling, sucking air from the sides with suction grilles, while the Model 2 is designed to air-conditioning with the aseptizer. For each designed model, five different sections along the X-plane and three along the z-plane were examined. In Model-1, it was observed that the dead winter regions were formed as a result of the positioning of the surgical lamps on the surgical area. In addition, it was observed that the temperature values in the room were not disturbing for the personnel and the patient. Because of the high air flow rate in the Model 2, it was seen that the operating room is uncomfortable the personnel due to high air flow rate and also surgical area infection development is possible due to the lack of laminar flow on the surgical area. When the results of the study are examined, it is seen that the most suitable air-conditioning
\end{abstract}

* Sorumlu Yazar: İskenderun Teknik Üniversitesi, Mühendislik ve Doğa Bilimleri Fakültesi, Makine Mühendisliği Bölümü, Hatay, Türkiye, yildiz.koc@iste.edu.tr 
system for the operating rooms in accordance with the standards and the results of the studies in the literature is air-blowing from the ceiling and air-sucking from the sides with suction grilles system, which is defined as Model 1 in the present study.

Keywords: Operating Room, Air Conditioning, Aseptizer, Modelling, Fluent.

\section{Giriş}

Ameliyathaneler hastaların en savunmasız olduğu ve ortamdaki olumsuz şartlardan en çok etkilendiği alanlardan birisidir. Sterilizasyon ve havalandırma sorunlarından dolayı ameliyathanelerde meydana gelen başlıca komplikasyon ve ölümlerin başında enfeksiyon gelmektedir. Amerika Birleşik Devletleri'nde ameliyathanelerde her 6 hastadan birisi enfeksiyon nedeni ile ölürken bu oran Avrupa ülkelerinde \% $\% 5^{\prime}$ lere kadar çıkmaktadır [1]. Üriner sistem enfeksiyonlarından sonra en sık karşılaşılan enfeksiyonlar cerrahi alan enfeksiyonlardır [2]. Ameliyathane, acil cerrahi müdahale bölümü, yoğun bakım üniteleri, bulaşıcı hastalık şüphesi olanların teşhis ve tedavi üniteleri vb. gibi önemli ortamlar enfeksiyonların en fazla görüldüğü yerlerdir [3]. Buralarda enfeksiyon miktarının artmasının en önemli nedeni hastaya steril olmayan ortamda ve steril olmayan biçimde müdahalede bulunulmasıdır. Hastanın kendisi, ameliyat aletleri, cerrahi kadro enfeksiyon miktarının artmasındaki diğer önemli etkenlerdir [4]. Dünya'da tahminen yıllık 234 milyon ameliyat gerçekleştirilmekte ve bu durum günden güne cerrahi alan enfeksiyonun görülme riskini arttırmaktadır [3]. Bu nedenle ameliyathane ortamlarının iklimlendirme sistemlerinin projelendirilmesinde daha fazla dikkat edilmesi gerekmektedir [5]. Çünkü hastanelerin riskli alanlarından birisi olan ameliyathanelerde enfeksiyon riskini arttıran en önemli faktörlerden birisi ameliyathanelerin havalandırılması ve soğutulmasında doğru iklimlendirme ve filtrasyon sisteminin seçilmemesidir.

Günümüze kadar ameliyathanelerde birçok iklimlendirme sistemleri kullanılmıştır. Tasarlanan iklimlendirme sistemlerinde sıcaklık, nem, üfleme hızı, cerrahi kadro ameliyathane cihazları gibi birçok etken göz önüne alınmıştır. Sıcaklığın ortalama $21^{\circ} \mathrm{C}$ olması ve statik elektriklenmeden dolayı oluşabilecek tehlikeleri engellemek için nemin \%30 ile \%60 aralığında olması gerekmektedir [6]. Sıcaklık ve nemin belirli bir oranda tutulması enfeksiyonun çoğalmasının minimize edilmesini, cerrahi kadronun daha rahat çalışmasını ve iklimlendirme sisteminin daha verimli olmasını sağlar. İklimlendirme ile eş zamanlı olarak ameliyathanede görev yapan cerrahi kadroda dikkate alınması gereken önemli parametrelerdendir. Personelin hareketinin hava akımı düzenini etkilemesi ve ameliyathane havasındaki enfeksiyonların ameliyathaneye giriş-çıkış yapan insan sayısı ile doğru orantılı olması cerrahi kadroya dikkat edilmesinin temel sebeplerindendir [7]. Bu nedenle ameliyathanelerde insan giriş çıkışı minimum düzeyde tutulmalıdır [8].

İklimlendirme de kullanılan havalandırma sistemlerinde istenilen sıcaklık ve nemin yanı sıra dışarıdaki havadan ameliyathane ortamına girmesi muhtemel olan toz ve partiküllerin temizlenebilmesi için, iklimlendirme sistemi ile entegre çalışan \%90 veya üzerinde havayı temizleye bilen filtrasyon sisteminin de olması önemlidir. Ayrıca kullanılan havalandırma sistemlerinde enfeksiyonlar üreyip çoğalma yoluyla daha fazla yayıldığı için ameliyathane havalandırma sisteminin bakımı düzenli olarak yapılmalı ve filtreler belirlenen zaman aralıklarında değiştirilmelidir [9,10]. Fakat, burada da tasarlanan iklimlendirme ve havalandırma sisteminin bakım ve onarımının yapılması esnasında, ameliyathanedeki çalışma düzenine etki etmemesi ve bakım sırasında içerisindeki zararlıları ameliyathane ortamına bırakmaması dikkat edilmesi gereken bir diğer önemli parametrelerdendir.

Bu çalışmada, Türkiye'de mevcut durumda bulunan bir devlet hastanesinin ameliyathanesinin iklimlendirilmesi sonucunda sıcaklık dağılımları incelenmiştir. Çalışma kapsamında ameliyathanenin incelenmesinde iki farklı model (Model 1 ve Model 2) tasarlanmış ve tasarlanan bu modeller ANSYS Fluent programı ile simüle edilerek sayısal olarak analiz edilmiştir. Model 1 tavandan üfleme, kenarlardan emme menfezleri ile hava emen bir sistem olarak tasarlanırken Model 2 aseptizör cihazı ile iklimlendirme yapacak şekilde tasarlanmıştır. Sicaklık dağılımın x ve z eksenler boyunca değişen mesafelerdeki dağılımını görmek, ameliyathanede bulunan ekipmanların sıcaklık dağılımına etkisini belirlemek ve ölü kış bölgelerini bulabilmek için; tasarlanan her bir modelde x düzlemi boyunca beş ve z düzlemi boyunca üç farklı kesitte inceleme yapılmıştır.

\section{Materyal ve Metot}

\subsection{Ameliyathanelerin İklimlendirilmesi}

Ameliyathaneler, hasta sağlığı açısından mikroorganizmaların bulunmadığı yerler olmalıdır. Bu nedenle ameliyathanelere özel iklimlendirme sistemleri tasarlanmaktadır. Genel olarak ameliyathanelerin iklimlendirilmesinde ortamın sıcaklığı ve nemi, personel aktiviteleri ve kıyafetleri, havanın akış yönü, hava basıncı, kullanılan aletlerin temizliği, ameliyathanenin günlük bakımları vb. gibi parametrelere dikkat edilmektedir. Ameliyathanelerin klima sistemlerinde; birinci adımda ön filtre (elyaf filtreler), ikinci adımda duyarlı filtre (torba filtreler) ve üçüncü adımda mutlak filtre (HEPA filtreler) kullanılmalıdır. Kokuların yok edilmesi ve korozyonu etkisini en aza indirgemek için kullanılan filtreler ise dördüncü adım filtreleri olarak kullanılabilmektedir [11].

Ameliyathanelerin iklimlendirilmesinde

1. Paket tip hijyen klima

2. Aseptizörler

3. Merkezi sistemler

kullanılmaktadır [12]. Aseptizörler ve paket tip hijyen klimalar \%30-\%100 arasında ki taze havayı alıp filtrelerden geçirip sonra \%70 e kadar ortamda ki havayla karıştırmaktadırlar. Sonrasında karıştırılan hava tekrar filtrelerden geçirilmektedir. İhtiyaca göre sıcaklığını değiştirme, içerisindeki nem miktarını ayarlama gibi işlemler yapılarak istenilen hava elde edilmektedir [12]. Aseptizörler ve paket tip hijyen klimalar en az \%30 temiz havayı kullanarak en fazla \%70 oranında ki iç ortam havasıyla karıştırarak havayı temizlemekte ve tekrar kullanıma hazırlamaktadır [12]. Taze hava ayarlanabilir olduğu için \%30-\%100 arasında ayarlanabilmektedir. Bu sistem aseptizör 
ve paket tip hijyen klimaların enerji maliyetini merkezi sistemlere göre $\% 60$ oranında düşürmektedir. Dahası aseptizör ve paket tip hijyen klimaların kurulumları basittir ve kurulması için fazla bir işlem gerektirmezler [12].

Klimalarda kullanılan HEPA filtrelerinin ömrü en az 1 en fazla 3 yıldır. Aseptizör ve paket tip hijyen klimaların havalandırma kanalları az ve küçük olduğundan bakım işlemleri daha kolay olur. Bakımları düzenli yapıldığı takdirde ise 15-20 yıl boyunca kullanılabilirler. Kapladığı hacim, merkezi sistemlere çok kü̧̈üktür ve taşınabilirlerdir [12].

Aseptizör ve paket tip hijyen klimalarında ultraviyole sistemlerde kullanılmaktadır. Ultraviyole sistemler, hava filtreden geçtikten sonra filtrede yakalanamayan 0,03 mikrondan küçük mikroorganizmaların DNA sisteminin bozarak etkisiz hale getirmektedir [12].

Aseptizörler; genel olarak duvardan direkt üflemeli ve laminer hava akış ünitesi olarak ikiye ayrılmaktadırlar [12]. Duvardan direkt üflemeli aseptizörlerde türbülanslı akış kullanılmaktadır. Türbülanslı hava akımı, havanın daha çok yayılmasını sağlar. Bu durum hava içerisinde mikroorganizmaların hızlı bir şekilde etrafa yayılmasını neden olur [9]. Etrafa yayıldıkları için çoğalmaları daha hızlı bir şekilde olur ve bu istenilen bir durum değildir. Hem bu nedenden dolayı hem de tavan yüksekliğinden dolayı diğer aseptizörlerin kullanılamadı̆̆g yerler de kullanılırlar.

Laminer hava akış ünitesinde ortama verilen havada laminer akış kullanılmaktadır. Laminer akış kullanımı daha hijyenik bir ortam sağlamaktadır. Dahası laminer akışla mikroorganizmaların yayılması minimum seviyelere düşürülür ve bu sayede bu organizmaların çoğalmaları engellenir [9]. Laminer hava akış üniteleri ultraviyole sistemleri de içermektedir. Laminer akış, havanın akışının homojen olmasını sağlamasının yanı sıra ameliyat masası ve çevresindeki mikroorganizmalarında ortalama $0,25 \mathrm{~m} / \mathrm{s}$ 'lik akış hızıyla dışarı atılmasını sağlar [13].

Merkezi sistemler; aseptizör ve paket tip hijyen klimalardan daha büyüktür. Ayrıca hava aktarımının sağlandığı kanallar daha uzun ve fazladır. Merkezi sistemler havayı ortamdan alırlar ve alınan hava direk filtrelere gönderildiği için hava içerisinde ki partiküller zamanla filtreye zarar verir buda filtre kullanım süresini azaltır. Filtre ömürleri kısa olacağı için 1 yıl içerisinde değiştirilmesi gerekir. Merkezi sistemler, havayı içerisinde ki partikülleri arındırmadan aldığı için hava aktarımını sağlayan kanallarda bulunan mikroorganizmaların da hızla artmasına neden olur [12]. Kanallar zamanla aşındı için basınç, verim ve debi kayıplarına yüksektir ve bu durumda maliyetin artmasına neden olur. Enerji maliyetleri diğer sistemlere göre daha fazladır. Merkezi sistemlerin kapladıkları hacim fazla olması nedeniyle genellikle ameliyathanelerin dışarısında kalır ve taşınması mümkün değildir. Ameliyathane dışarısında kalması temiz havanın ameliyathaneye gelme süresini uzatır ve iç yapısının değişmesine neden olur. Bu yüzden istenilen verim elde edilemez [12].

\subsection{Modellenen Sistemin Tasarım Parametreleri}

Deney sisteminde kullanılan ameliyathane, Türkiye'de bulunan bir devlet hastanesi içerisinde bulunan ameliyathanenin fiziki ölçüleriyle aynıdır. Ameliyathane $600 \mathrm{~cm}$ eninde $600 \mathrm{~cm}$ boyunda $290 \mathrm{~cm}$ yüksekliğindedir. Model 1 ve Model 2 olarak iki farklı iklimlendirme sistemi kullanılmıştır. Deneyde kullanılan her iki iklimlendirme sistemi de yaz ve kış şartlarındaki çalışma durumunun belirlene bilmesi için ocak ve temmuz ayları için modellenmiştir.

\section{Model 1'in tasarm parametreleri:}

Model 1 için; tavandan üfleme yapan 6 adet $57 \times 59 \mathrm{~cm}$ üfleme menfezi ve yan duvarlardan emme yapan 2 adet $14 \times 29 \mathrm{~cm}$ emme menfezi kullanılmıştır. Çalışma boyunca hava hızı $0,4 \mathrm{~m} / \mathrm{s}$ olarak alınmıştır.

Ocak ayı için;

Ortam havasının sıcaklığı: $15^{\circ} \mathrm{C}$

Üfleme havasının sıcaklığı: $21^{\circ} \mathrm{C}$

Temmuz ayı için;

Ortam havasının sicaklı̆̆ $1: 25^{\circ} \mathrm{C} \quad$ Üfleme havasının sicaklığı: $20^{\circ} \mathrm{C}$

olarak alınmıştır.

Tablo 1. Model 1'de Ameliyathane İçerisinde Bulunan Cihaz ve İnsanların Ölçüleri ve Isı Yayım Değerleri

\begin{tabular}{|l|c|c|}
\hline & Ölçüler & Isı Yayımı \\
\hline Ameliyat Masası & 190x60x70 cm & Yok \\
\hline Cerrahi ışılar & $\begin{array}{l}70 \mathrm{~cm} \text { çap,25 cm yükseklikte yarı küre } \\
50 \mathrm{~cm} \text { çap,20 cm yükseklikte yarı küre }\end{array}$ & $50^{\circ} \mathrm{C}$ \\
& $20 \times 66 \times 175 \mathrm{~cm}$ \\
\hline Cerrahi kadro & $20 \times 25 \mathrm{~cm}$ & $37^{\circ} \mathrm{C}$ \\
\hline Cerrahi alan & & $37^{\circ} \mathrm{C}$ \\
\hline
\end{tabular}


European Journal of Science and Technology

\begin{tabular}{|l|c|c|}
\hline Hasta & $20 \times 60 \times 175 \mathrm{~cm}$ & $20{ }^{\circ} \mathrm{C}$ \\
\hline Anestezi makinesi & $60 \times 65 \times 145 \mathrm{~cm}$ & $70{ }^{\circ} \mathrm{C}$ \\
\hline Koter cihazl & $38 \times 38 \times 103 \mathrm{~cm}$ & $45{ }^{\circ} \mathrm{C}$ \\
\hline Monitör ve standl & $\begin{array}{c}\text { Monitör } 10 \times 40 \times 35 \mathrm{~cm} \\
\text { Stant; } 45 \times 50 \times 130 \mathrm{~cm}\end{array}$ & $40{ }^{\circ} \mathrm{C}$ \\
\hline Cerrahi alet masasl & $60 \times 95 \times 85 \mathrm{~cm}$ & Yok \\
\hline Ilaç dolabı & $50 \times 70 \times 170 \mathrm{~cm}$ & Yok \\
\hline Üfleme menfezi & $57 \times 59 \mathrm{~cm}$ & Yok \\
\hline Emme menfezi & $14 \times 29 \mathrm{~cm}$ & Yok \\
\hline
\end{tabular}
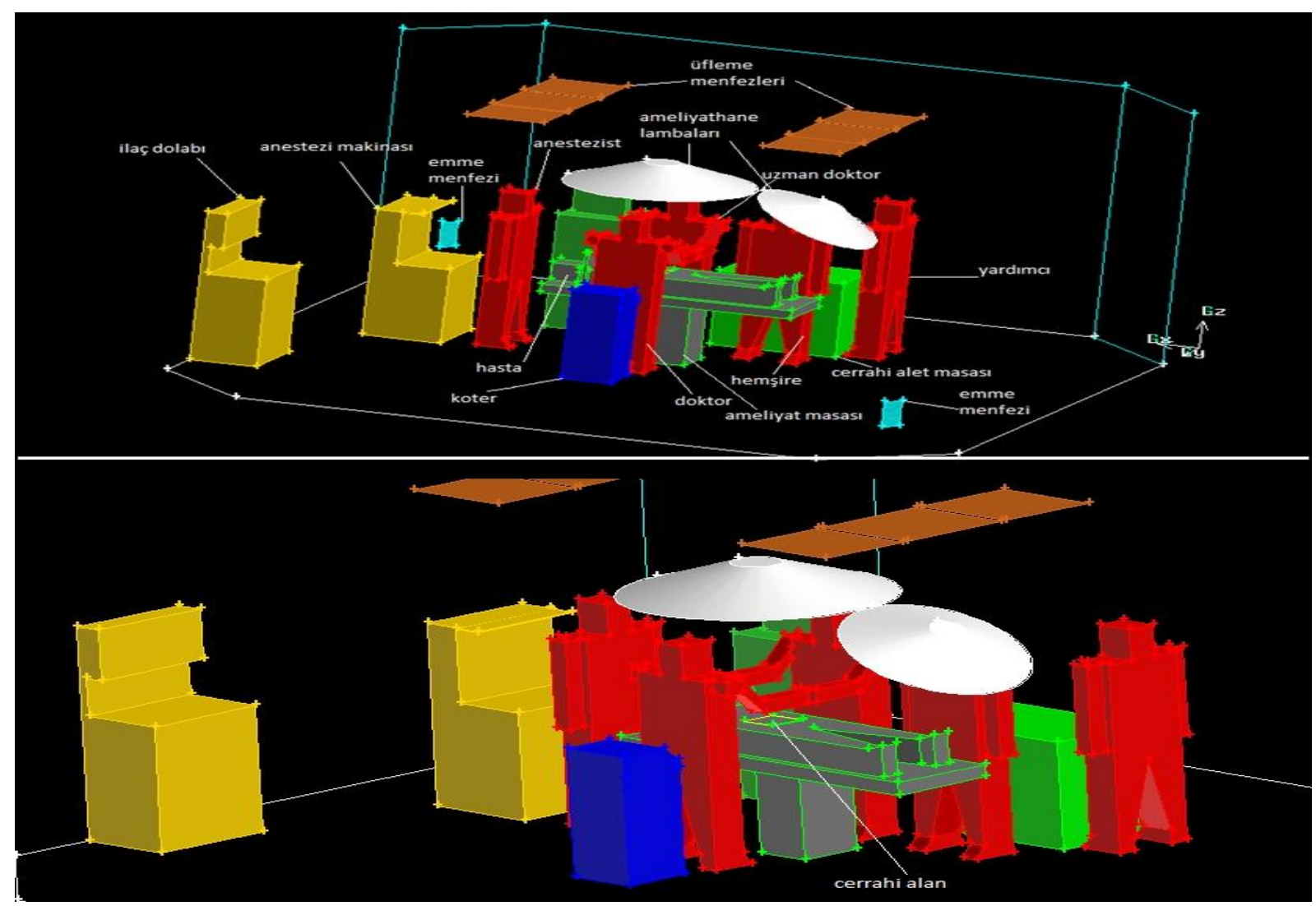

Şekil 1. Model 1 için yapılan çalışmada ameliyathanenin ve içerisindekilerin şematik gösterimi

\section{Model 2'in tasarm parametreleri:}

Model 2'nin iklimlendirmesi için kullanılan aseptizör cihazında 2 adet $54 \times 54 \mathrm{~cm}$ üfleme çıkışı, 2 adet 35x60 cm emme girişi bulunmaktadır. Kullanılan asptizör sisteminde sıcaklık $16-25{ }^{\circ} \mathrm{C}$ aralığında ayarlanabilirken bağıl nem değeri de \%30-\%70 aralığında tutulabilmektedir. Hava üfleme hızı $1 \mathrm{~m} / \mathrm{s}$ olarak kabul edilmiştir.

Ocak ayı için;

Ortam havasının sıcaklı̆̆ı: $15^{\circ} \mathrm{C} \quad$ Üfleme havasının sıcaklı̆̆ı:21 ${ }^{\circ} \mathrm{C}$

Temmuz ayı için;

Ortam havasının sıcaklı̆̆ $1: 25^{\circ} \mathrm{C} \quad$ Üfleme havasının sıcaklığı:17 ${ }^{\circ} \mathrm{C}$

olarak alınmıştır. 
Tablo 2. Model 2'de Ameliyathane İçerisinde Bulunan Cihaz ve Insanların Ölçüleri ve Isı Yayım Değerleri

\begin{tabular}{|c|c|c|}
\hline & Ölçüler & Isı Yayımı \\
\hline Ameliyat Masası & $190 \times 60 \times 70 \mathrm{~cm}$ & Yok \\
\hline Cerrahi ışıklar & $\begin{array}{l}70 \mathrm{~cm} \text { çap, } 25 \mathrm{~cm} \text { yükseklikte yarı küre } \\
50 \mathrm{~cm} \text { çap, } 20 \mathrm{~cm} \text { yükseklikte yarı küre }\end{array}$ & $\begin{array}{l}50^{\circ} \mathrm{C} \\
40^{\circ} \mathrm{C}\end{array}$ \\
\hline Cerrahi kadro & $20 \times 66 \times 175 \mathrm{~cm}$ & $37^{\circ} \mathrm{C}$ \\
\hline Cerrahi alan & $20 \times 25 \mathrm{~cm}$ & $37^{\circ} \mathrm{C}$ \\
\hline Hasta & $20 \times 60 \times 175 \mathrm{~cm}$ & $20{ }^{\circ} \mathrm{C}$ \\
\hline Anestezi makinesi & $60 \times 65 \times 145 \mathrm{~cm}$ & $70{ }^{\circ} \mathrm{C}$ \\
\hline Koter cihazl & $38 \times 38 \times 103 \mathrm{~cm}$ & $45^{\circ} \mathrm{C}$ \\
\hline Monitör ve standl & $\begin{array}{l}\text { Monitör; 10x40x35 cm } \\
\text { Stant; 45x50x130 cm }\end{array}$ & $40{ }^{\circ} \mathrm{C}$ \\
\hline Cerrahi alet masasi & $60 \times 95 \times 85 \mathrm{~cm}$ & Yok \\
\hline İlaç dolabı & $50 \times 70 \times 170 \mathrm{~cm}$ & Yok \\
\hline Aseptizör cihazl & $55 \times 135 \times 220 \mathrm{~cm}$ & Yok \\
\hline
\end{tabular}
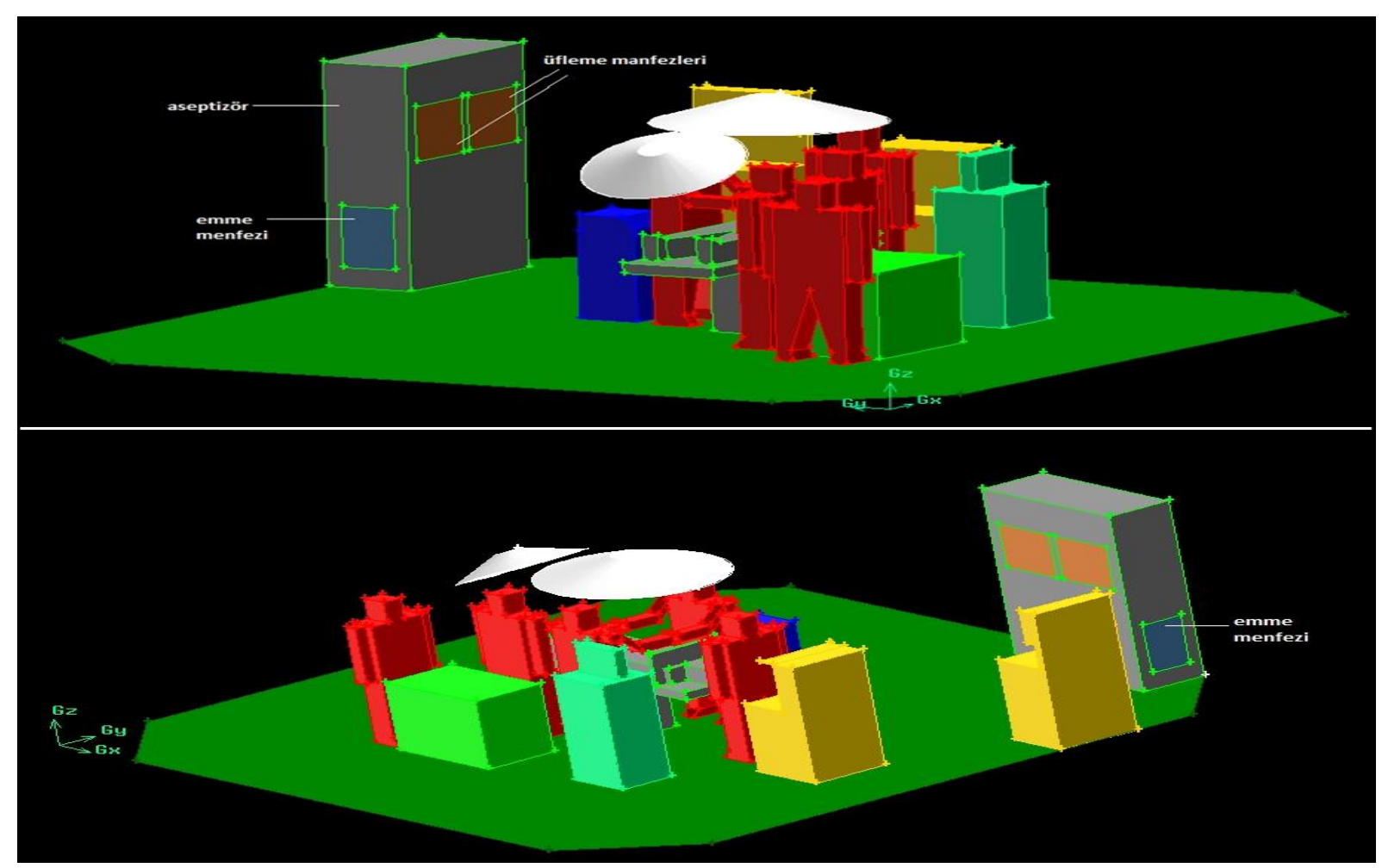

Şekil 2. Model 2 için yapılan çalışmada ameliyathanenin ve içerisindekilerin şematik gösterimi 
Model 1 ve Model 2'de üfleme menfezi çıkışlarındaki ve cerrahi kadronun etrafındaki hava akışının en iyi şekilde incelenmesi için; $\mathrm{x}$ düzleminde 5 ayrı kesit alınmıştır. Ayrıca, cerrahi kadronun rahat çalışmasının incelenmesi için personelin baş seviyesindeki kesiti, cerrahi alandaki hava akışının incelenmesi için cerrahi alan üstündeki kesit ve zemindeki havanın akışını incelemek için zemin seviyesi kesitlerini incelemek için 3 farklı $\mathrm{z}$ kesiti incelenmiştir.

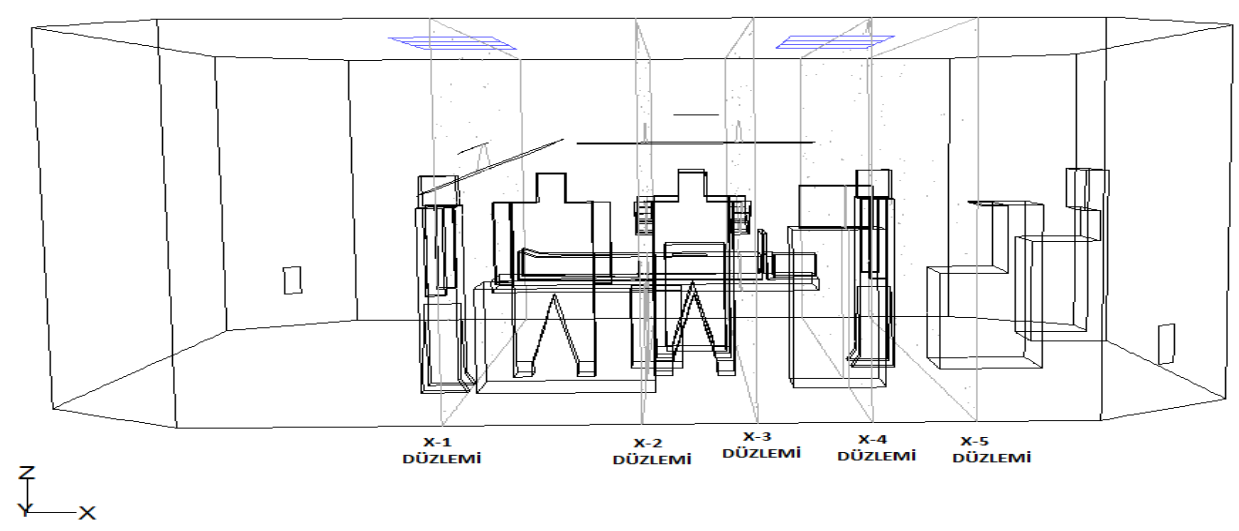

Şekil 3. Model 1 için x düzleminde alınan kesit görünüşleri

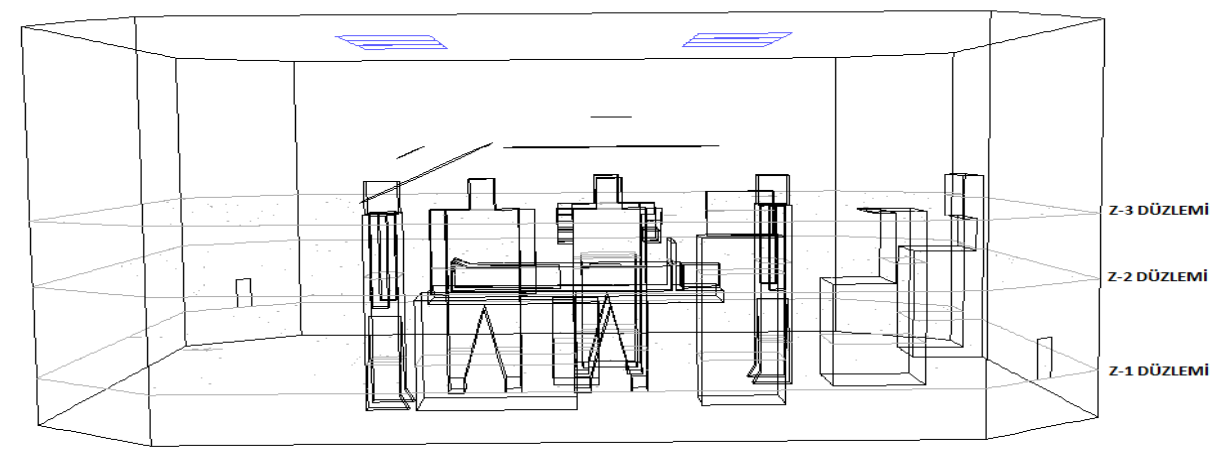

$\underset{i}{i}$

Şekil 4. Model 1 için z düzleminde alınan kesit görünüşleri

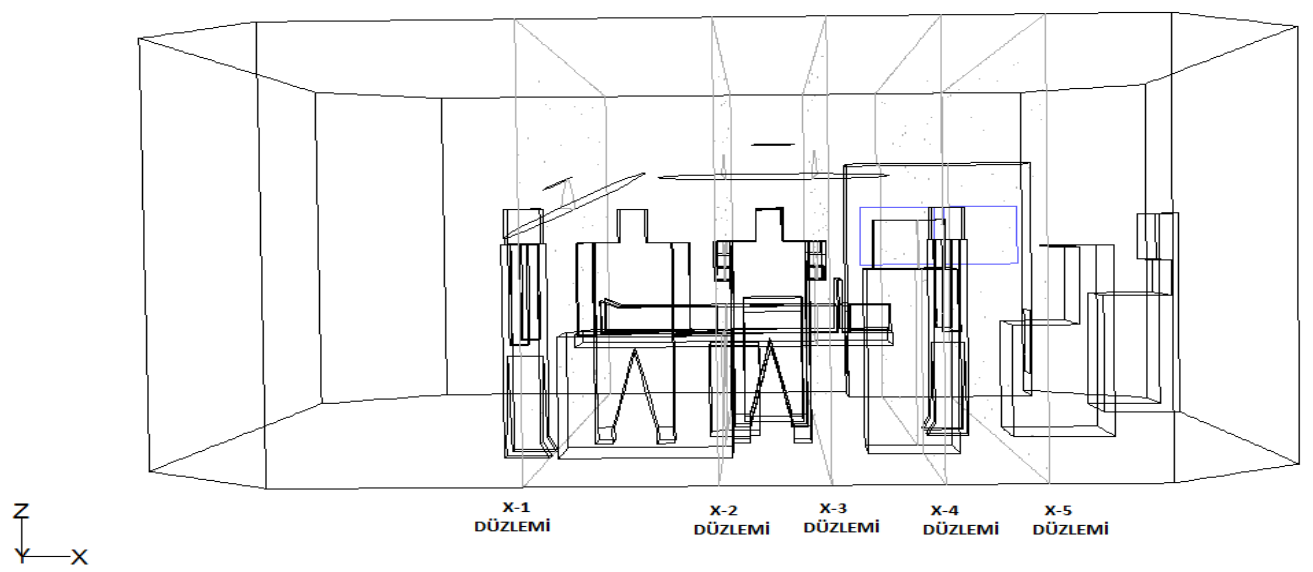

Şekil 5. Model 2 için x düzleminde alınan kesit görünüşleri 


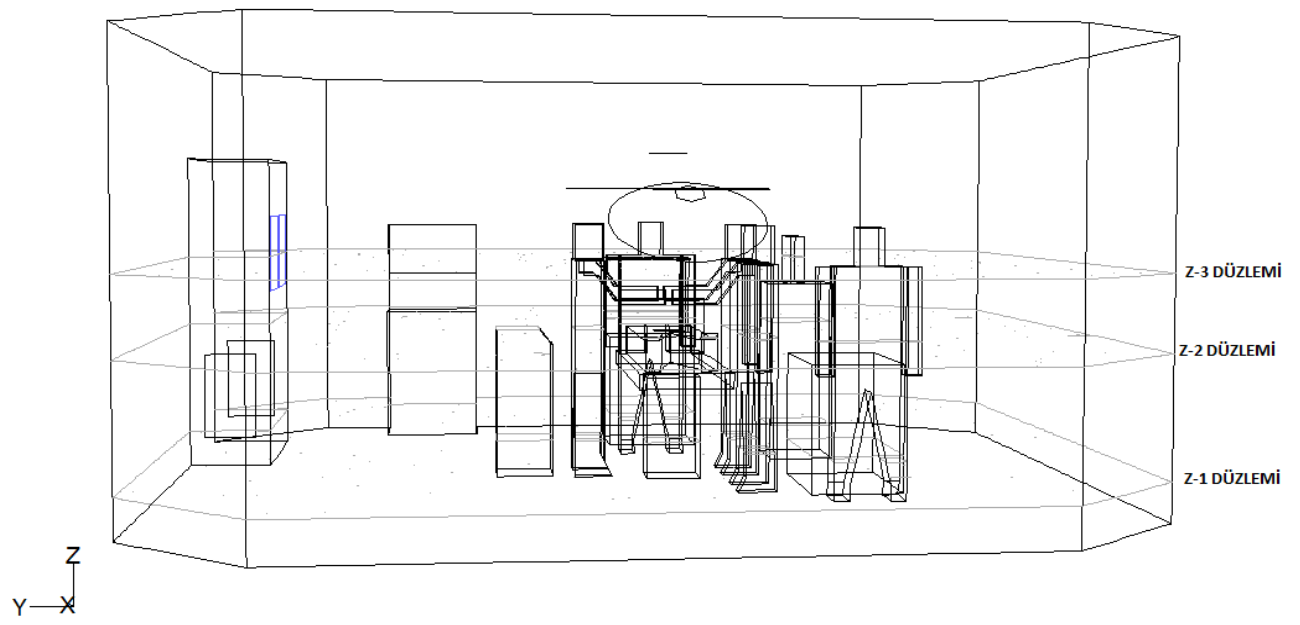

Şekil 6. Model 2 için z düzleminde alınan kesit görünüşleri

\subsection{Matematiksel Model ve Kabuller}

Akışkan dinamiğinin çözümü ve modellenmesi için ANSYS Fluent 6.3 programı kullanılmıştır. Fakat program içeriğinde ameliyathane şeklini oluşturmak için çizim programı bulunmamaktadır. Bu nedenle ameliyathanenin tasarımı için Fluent 6.3 programıla uyumlu olan Gambit çizim programı kullanılmıştır. Gambit programı ile tasarlanan ameliyathane sonrasında Fluent 6.3 programına aktarılmış ve sistemin modellemesi yapılmıştır. Ameliyathanedeki ekipmanlar ve cerrahi kadronun yerleşim planının belirlenmesinde Memarzadeh ve Manning'in çalışmalarında kullandıkları yerleşim planı baz alınmıştır [14].

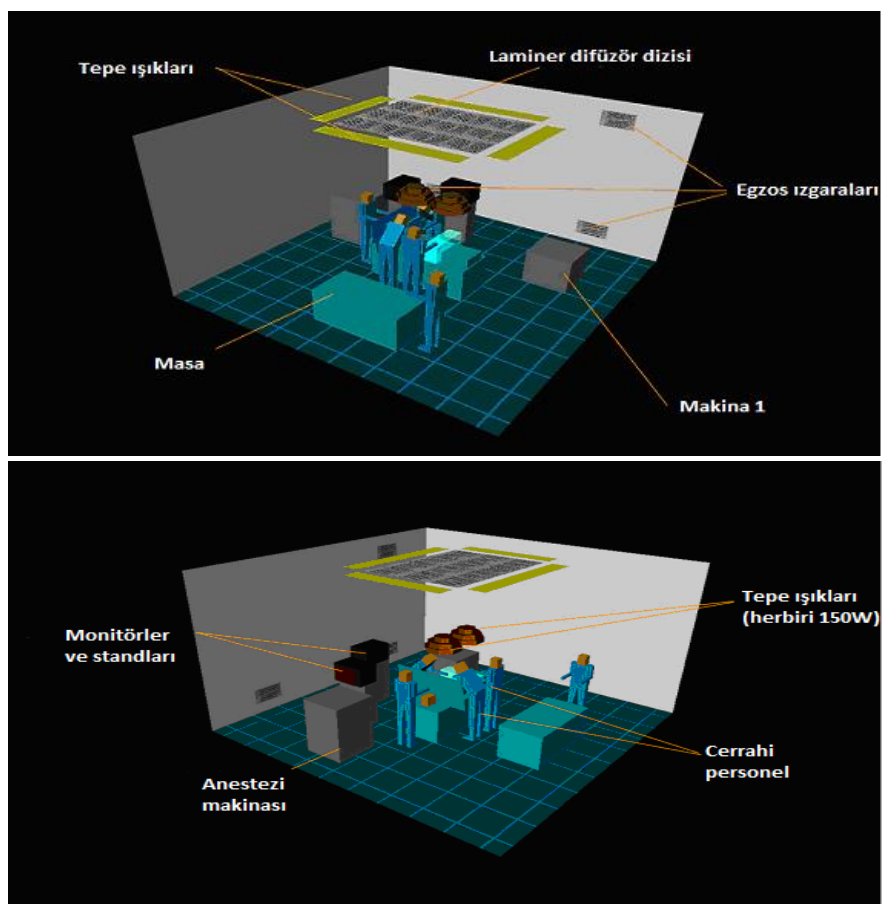

Şekil 7. Memarzadeh ve Manning’in çalışmalarında kullandıkları yerleşim planı [14]

Çalışmada kullanılan hava, ideal gaz ve sıkıştırılamaz olarak kabul edilmiştir. Yapılan kabuller doğrultusunda kararsız akım için süreklilik denklemi, enerji denklemleri, hareket denklemleri ve türbülanslı akım oluşması durumunda k- $\varepsilon$ türbülanslı denklemleri belirlenmiştir. Sürekli rejim şartlarında üç boyutlu sıkıştırılamaz laminer akım için süreklilik denklemi;

$\frac{\partial u}{\partial x}+\frac{\partial v}{\partial y}+\frac{\partial w}{\partial z}=0$

şeklinde ifade edilmiştir. Burada,

$u$ : x yönünde ki hareket hızı

v: y yönünde ki hareket hızı 
$w: \mathrm{z}$ yönünde ki hareket hızı

belirtmektedir. Süreklilik şartlarında momentum denklemleri;

$\frac{\partial u}{\partial t}=0 \quad \frac{\partial v}{\partial t}=0 \quad \frac{\partial w}{\partial t}=0$

olarak yazılabilmektedir. $\mathrm{x}$ doğrultusunda;

$u \frac{\partial u}{\partial x}+v \frac{\partial u}{\partial y}+w \frac{\partial u}{\partial z}=-\frac{1}{\rho} \frac{\partial P}{\partial x}+\mu\left(\frac{\partial^{2} u}{\partial x^{2}}+\frac{\partial^{2} u}{\partial y^{2}}+\frac{\partial^{2} u}{\partial z^{2}}\right)$

y doğrultusunda;

$u \frac{\partial v}{\partial x}+v \frac{\partial v}{\partial y}+w \frac{\partial v}{\partial z}=-\frac{1}{\rho} \frac{\partial P}{\partial y}+\mu\left(\frac{\partial^{2} v}{\partial x^{2}}+\frac{\partial^{2} v}{\partial y^{2}}+\frac{\partial^{2} v}{\partial z^{2}}\right)+g \beta\left(T-T_{1}\right)$

$\mathrm{z}$ doğrultusunda;

$u \frac{\partial w}{\partial x}+v \frac{\partial w}{\partial y}+w \frac{\partial w}{\partial z}=-\frac{1}{\rho} \frac{\partial P}{\partial z}+\mu\left(\frac{\partial^{2} w}{\partial x^{2}}+\frac{\partial^{2} w}{\partial y^{2}}+\frac{\partial^{2} w}{\partial z^{2}}\right)$

$\mathrm{Bu}$ eşitliklerde;

$\beta$ : Isıl genleşme katsayısını

$T$ : Ortam sıcaklı̆̆ını

$T_{1}$ : İşlem sırasındaki sıcaklı̆̆g

ifade etmektedir. Enerji denklemi ise;

$u \frac{\partial T}{\partial x}+\frac{\partial T}{\partial y}+w \frac{\partial T}{\partial z}=\alpha\left(\frac{\partial^{2} T}{\partial x^{2}}+\frac{\partial^{2} T}{\partial y^{2}}+\frac{\partial^{2} T}{\partial z^{2}}\right)$

eşitliği şeklinde yazılır. Isıl difüzyonu ifade eden $\alpha$,

$\alpha=\frac{k}{c_{p}}$

formülüyle hesaplanır. Burada;

$\alpha$ : Isıl difüzyon katsayısını $\left(\mathrm{m}^{2} / \mathrm{s}\right)$

$k$ : Isı iletim katsayısını $(\mathrm{W} / \mathrm{mK})$

$c_{p}$ : Sabit basınç altında özgül 1sıyı $(\mathrm{J} / \mathrm{kgK})$

ifade etmektedir. Bu denklemler Fluent 6.3 programında belirlenmiş sınır şartları altında çözülerek tasarlanmış olan sistemlerin kabuller altında modellemesi yapılmıştır.

Bu denklemleri çözmek için Boussinesq yaklaşımı basit iterasyon yöntemi ve kapalı şema çözümleme yöntemi uygulanmıştır. Basit iterasyon yöntemi kararlı ve kararsız akımlar için kullanılmaktadır. Yapılan çalışmada akım lineer olmayan kararsız bir akım olduğundan iteratif sonlu farklar çözüm yöntemi kullanılmıştır. Bunun nedeni ise kapalı hacimlerde ısı transferi ve akışkan hareketi problemlerinin çözümü için süreklilik, enerji ve momentum denklemlerinin aynı anda çözülmesi gerekmesidir. Fakat, bu üç denklem de lineer olmayan kısmi diferansiyel denklemlerdir ve analitik olarak çözülememektedirler.

Denklemlerin çözülmesi için ilk önce cebirsel denklemlere dönüştürülmeleri gerekir. Cebirsel denklemlere dönüştürmek için Taylor serisi kullanılır. Dönüştürmelerde merkezi, ileri ve geri farklar kullanılmıştır. Taylor serisi ile elde edilen cebirsel denklemlerin çözümü için Succesive Under Relexation (SUR) metodu kullanılmıştır. Çözüm için akış alanı küçük parçalara bölünmüştür. Teorik olarak çözümün akış alanının her bir noktası için yapılması gerekmektedir. Fakat bu durum sonsuz sayıda nokta ve sonsuz sayıda denklem demektir. Bu nedenle akış alanı küçük bölgelere bölünerek bölgelerin kesiştiği noktalara elde edilen cebirsel denklemler uygulanmıştır. Çözümün hassasiyetini etkileyen durumlardan birisi cebirsel denklemlerin uygulandığı yerler olan düğüm noktalarıdır. Bu nedenle optimal düğüm sayısının belirlenmesi çok önemlidir.

Boussinesq yaklaşımında ise sıcaklık farkının düşük olduğu durumlarda momentum denklemleri yazılırmış ve yoğunluğun sıcaklığa bağlı olduğu kabul edilerek y yönündeki kaldırma kuvvetinde ki yoğunluk değişimi değişken $\mathrm{x}$ ve z yönündeki yoğunluklar ise sabit alınmıştır.

\section{Araştırma Sonuçları ve Tartışma}

Çalışma kapsamında var olan bir ameliyathane için iklimlendirme sisteminin Fluent 6.3 programı kullanılarak modellemesi yapılmıştır. Ameliyathane için belirlenen Model 1 ve Model 2 tasarımları için sabit ocak ve temmuz ayı ortalama sıcaklıkları ile Tablo 1 ve Tablo 2'de kabuller bir arada ele alınmış ve fluent programından 1 saatlik çalışma süresi boyunca elde edilen akış görüntüleri kaydedilmiştir. x ve z eksenlerinde belirlenen kesitlerden alınan akış modelleri detaylı olarak incelenmiştir. Model 1 ve Model 2'nin ocak ayında x düzlemlerindeki sıcaklık konturları Şekil 8'de verilmektedir. 


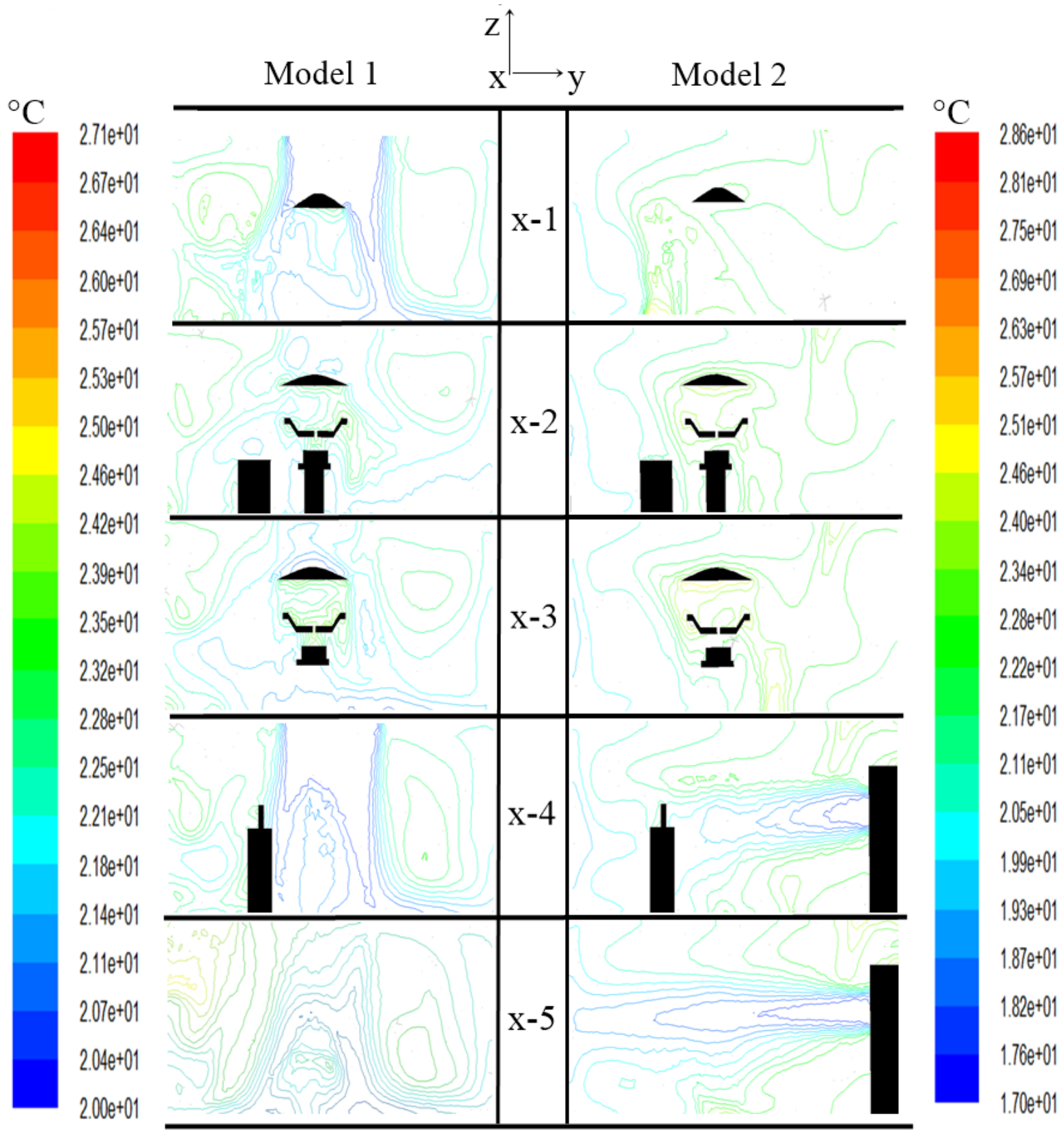

Şekil 8. Model 1 ve Model 2 için ocak ayında x düzlemlerindeki sıcaklık konturları $\left({ }^{\circ} \mathrm{C}\right)$

Şekilde her bir satırdaki resimler x ekseni boyunca 5 farklı kesitten alınan görüntülerdir. Sol taraftaki sütun ve sıcaklık dağılım skalası Model 1 için alınan sonuçları ifade ederken sağ taraftaki sütun ve sıcaklık dağılım skalası Model 2 için alınan sonuçları ifade etmektedir. Model 1 için elde edilen görüntüler incelendiğinde x-1 kesitinde üfleme menfezi çıkışında ameliyat lambası altında sıcaklığın yaklaşık olarak $20^{\circ} \mathrm{C}$ olduğu, diğer bölgelerde ise $18^{\circ} \mathrm{C}$ olduğu görülmektedir. Ameliyat lambasının altı ölü bölge olmasına rağmen sıcaklığın $20^{\circ} \mathrm{C}$ olmasının temel nedeni ameliyat lambasının ve cerrahi kadronun ürettiği ısıdır.

Ocak ayında Model 1 için x-2 kesitinde alınan görüntü incelendiğinde ameliyat lambası ve cerrahi kadronun bulunduğu bölgede sıcaklı̆̆ın yaklaşı $21{ }^{\circ} \mathrm{C}$ olduğu görülmüştür. Diğer bölgelerde ise sıcaklık $18^{\circ} \mathrm{C}$ civarındadır. Bu sonuçlar bir arada irdelendiğinde ameliyat masasının ve cerrahi alet masasının sıcaklık dağılımına etkisi belirgin bir şekilde görülmektedir.

Ocak ayında Model 1 için x-3 kesitindeki hesaplamalarda cerrahi kadronun bulunduğu bölgede sıcaklık $21{ }^{\circ} \mathrm{C}$ civarında ve diğer bölgelerde $18^{\circ} \mathrm{C}$ civarında hesaplanmıştır.

Ocak ayında Model 1'in x-4 kesitinde, cerrahi alet masası ile monitör standı arasındaki bölgeden sürüklenen havanın etkisiyle kesitin orta kısmının küçük bir alanında sıcaklığın $21{ }^{\circ} \mathrm{C}$ civarında olduğu ve ameliyathanenin diğer bölgeleri $18{ }^{\circ} \mathrm{C}$ olduğu görülmektedir.

Ocak ayında Model 1 için x-5 kesitinin orta kısmında anestezi makinesi önünde $23^{\circ} \mathrm{C}$ 'lik küçük bir bölgenin oluştuğu ve incelenen kesitin solunda ölü akış bölgesi oluşmasından dolayı $17{ }^{\circ} \mathrm{C}$ sıcaklıkta bir bölge oluştuğu görülmüştür. Ameliyathanenin diğer bölgelerinin sıcaklığı ise $18^{\circ} \mathrm{C}^{\prime}$ dir. 
Ocak ayında Model 2'de incelenen x kesitlerinde cerrahi alanda ve cerrahi kadronun bulunduğu alanda sıcaklığın $21^{\circ} \mathrm{C}$ civarında olduğu ve bu alanda yerden personelin baş hizasına kadar olan seviyede sıcaklık değerlerinin standartlarda belirlenen sınırlara uyduğundan dolayı sıcaklık yönünden Model 2 de kritik bir durumun oluşmadığı görülmüştür.

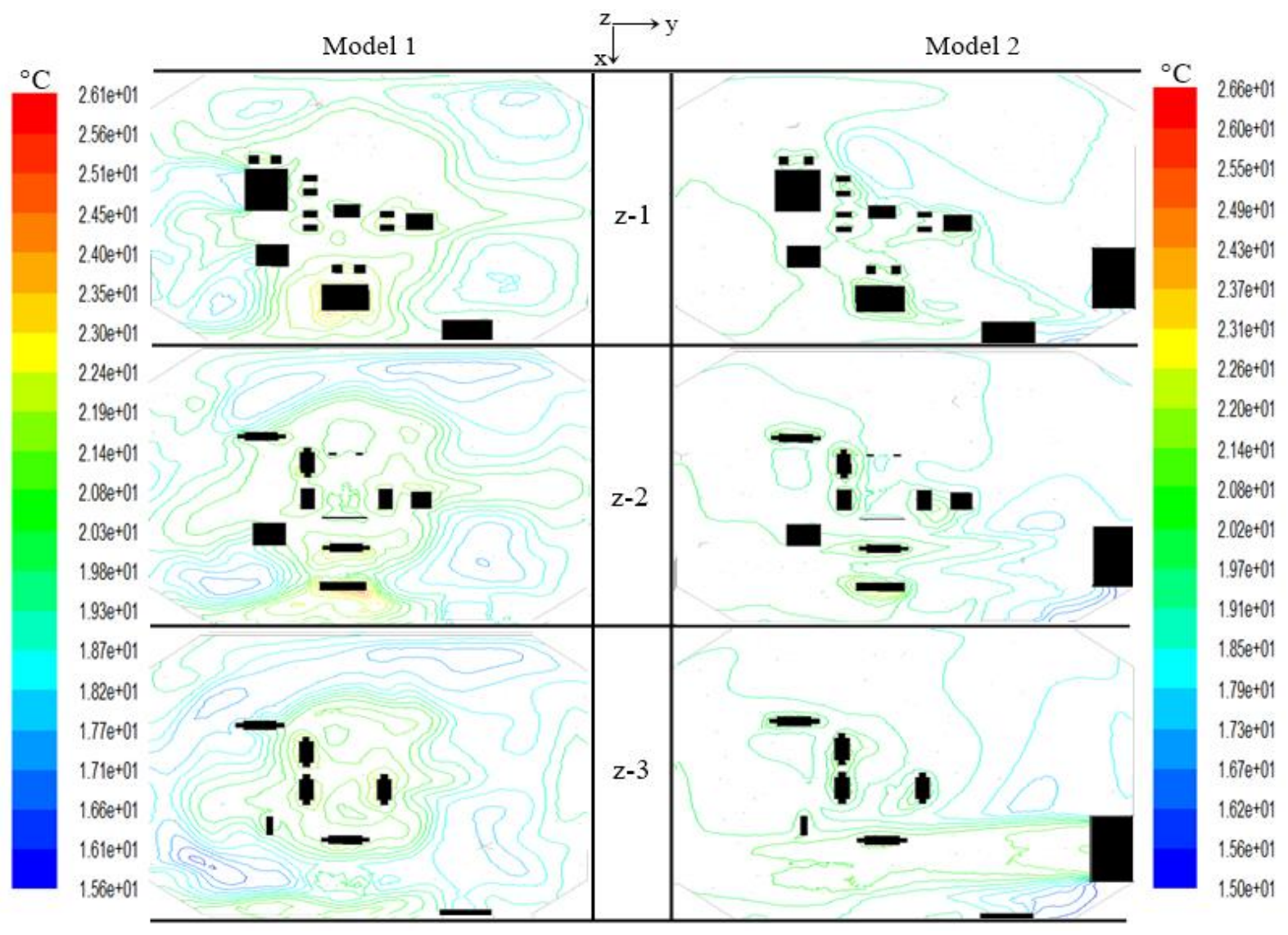

Şekil 9. Model 1 ve Model 2 için ocak ayında z düzlemlerindeki sıcaklık konturları $\left({ }^{\circ} \mathrm{C}\right)$

Ocak ayında Model 1 için z-1 kesitinin orta bölgesinde $21^{\circ} \mathrm{C}$ civarında bir sıcaklığın hakim olduğu görülmektedir. Köşe bölgelerde ise sıcaklık $18{ }^{\circ} \mathrm{C}$ civarındadır. Ameliyathane içerisinde bulunan engellerden dolayı sıcaklık farklı bölgelerde değişiklik göstermektedir.

Ocak ayında Model 1'in z-2 kesitinde ise z-1 kesitindekine benzer bir durum vardır. Sıcaklık orta bölgede $21^{\circ} \mathrm{C}$ civarında ve köşe bölgelerde $18{ }^{\circ} \mathrm{C}$ civarındadır. Burada sıcaklığın orta bölgeden kenar bölgelere doğru azaldığ 1 görülmektedir.

Ocak ayında Model 1 'in z-3 kesitinde sicaklık orta bölgede $21{ }^{\circ} \mathrm{C}$ civarında, orta bölgenin alt kısmında anestezi makinesinin oluşturduğu ısıdan dolayı $22^{\circ} \mathrm{C}$ civarında ve hava akışının az olduğu kısımlarda $17^{\circ} \mathrm{C}$ ile $18{ }^{\circ} \mathrm{C}$ arasında olduğu görülmektedir.

Ocak ayında Model 2'de incelenen z kesitlerinde cerrahi alanda ve cerrahi kadronun bulunduğu alanda sıcaklığın $21{ }^{\circ} \mathrm{C}$ civarında olduğu ve bu alanda yerden personelin baş hizasına kadar olan seviyede sıcaklık değerlerinin standartlarda belirlenen sınırlara uyduğundan dolayı sıcaklık yönünden Model 2 de kritik bir durumun oluşmadığı görülmüştür. Şekil 9'da Model 2'de aseptizör sağ kısma doğru üfleme yaparken üfleme menfezleri sol kısma doğru üfleme yapmaktadır. Sıcaklık sağdan sola doğru katmanlı olarak artmaktadır. 


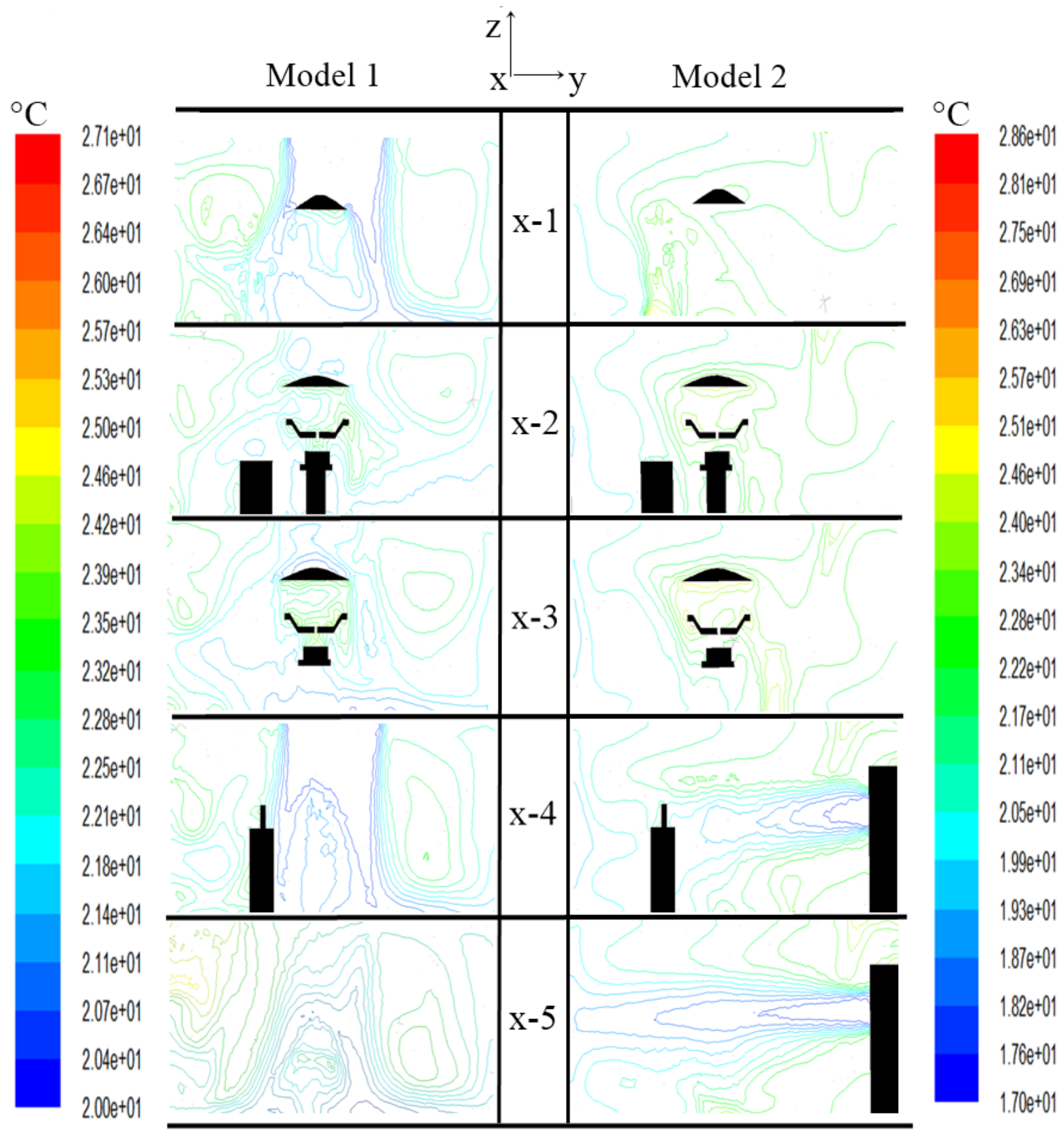

Şekil 10. Model 1 ve Model 2 için temmuz ayında x düzlemlerindeki sıcaklık konturları $\left({ }^{\circ} \mathrm{C}\right)$

Temmuz ayında Model 1 için incelenen x kesitinde cerrahi alanda ve cerrahi kadronun bulunduğu bölgede sıcaklı̆ğı $23^{\circ} \mathrm{C}$ civarında olduğu ve bu bölgede yerden personelin baş hizasına kadar olan seviyede sıcaklık değerlerinin standartlarda belirlenen sinırlara uyduğu görülmüştür. Standartlarda belirlenen sınırlara uyduğundan dolayı sıcaklık yönünden Model 1'in x-kesitlerinde kritik bir durum oluşmamıştır. Ameliyathane lambalarından kaynaklanan 1sının oluşturduğu alan Şekil 10'da Model 1 için alınan x-1, x-2 ve x-3 kesitlerinde net bir şekilde görülmektedir. Model 1'de üfleme menfezlerinden çıkan havanın ameliyathane lambalarına çarparak etrafa dağılmasından dolayı cerrahi alan üzerinde verimli bir iklimlendirme yapılamadığı görülmüştür. 


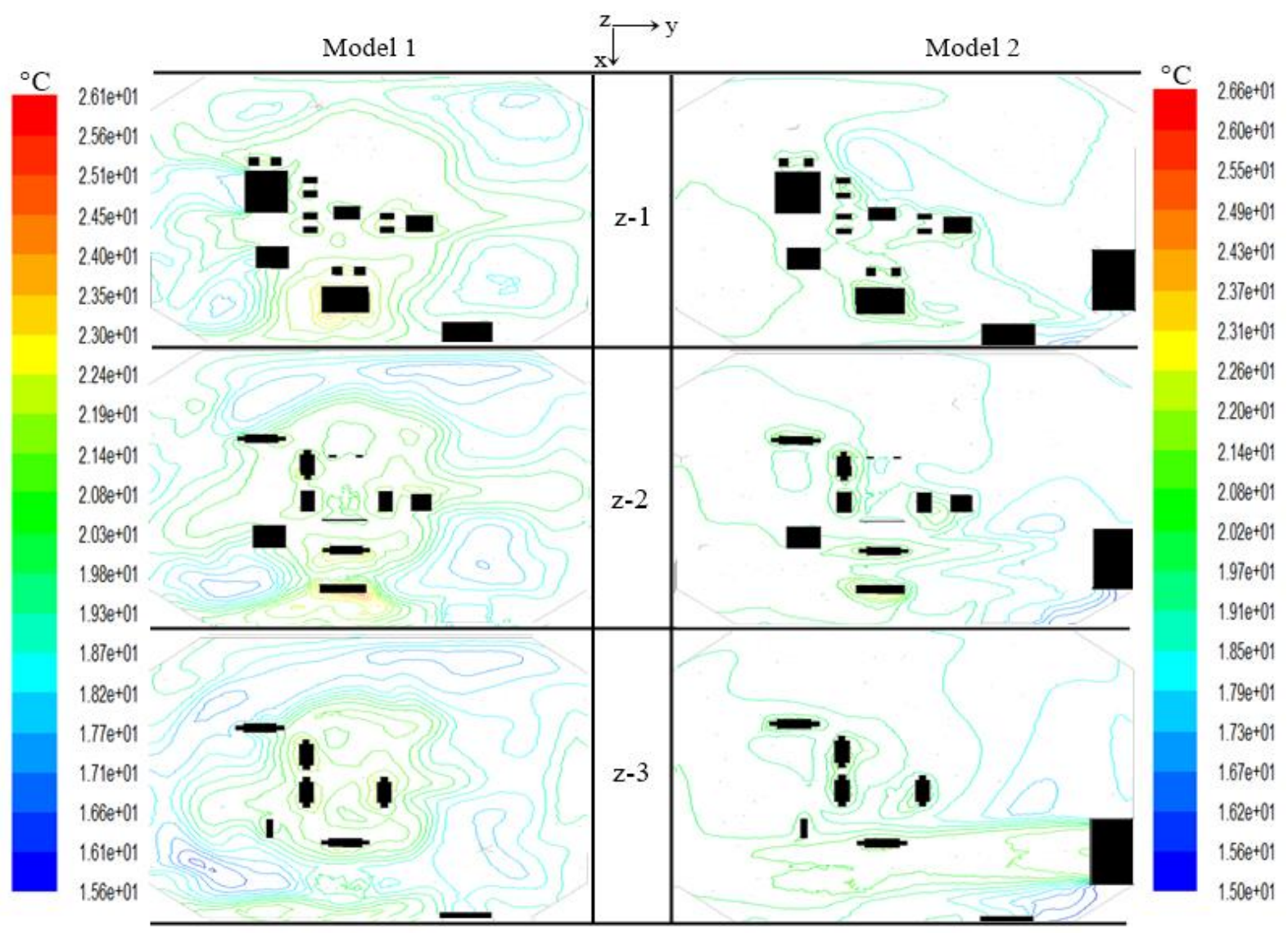

Şekil 11. Model 1 ve Model 2 için temmuz ayında z düzlemlerindeki sıcaklık konturları $\left({ }^{\circ} \mathrm{C}\right)$

Temmuz ayında Model 1 için alınan z kesitleri incelendiğinde üfleme menfezlerinin alt bölgelerinin yaklaşık olarak $20^{\circ} \mathrm{C}$ civarında olduğu görülmektedir. Salonun diğer bölgelerinde $23^{\circ} \mathrm{C}$ sıcaklık görülmekte olup sıcaklığın yukardan aşağıya doğru artış gösterdiği de açık bir şekilde görülmektedir. Buda ameliyat lambalarının cerrahi alan üzerinde bulunmasından kaynaklanmaktadır.

Temmuz ayında Model 2'de incelenen x ve z kesitlerinde cerrahi alanda ve cerrahi kadronun bulunduğu alanda sıcaklığın yaklaşık olarak $22{ }^{\circ} \mathrm{C}$ olduğu ve bu alanda yerden personelin baş hizasına kadar olan seviyede sıcaklık değerlerinin standartlarda belirlenen sınırlara uyduğu gözlemlenmiştir. Sıcaklık değerlerinin standartlarda belirlenen sınırlara uymasından dolayı sıcaklık yönünden Model 1 gibi Model 2'de de kritik bir durumun oluşmadığı görülmüş̧ür. Model 2'de aseptizör, sağ kısma doğru üfleme yaparken üfleme menfezleri sol kısma doğru üfleme yapmaktadır. Sıcaklık sağdan sola doğru katmanlı olarak artmaktadır. Şekil 10'da Model 2 için x-4 ve x-5 kesitlerinde aseptizörün üfleme menfezleri çıkışlarında sıcaklığın sağdan sola doğru katmanlı olarak arttığı görülmüştür.

\section{Sonuç}

Bu çalışmada, Türkiye'de mevcut durumda bulunan bir devlet hastanesinin ameliyathanesinin iklimlendirilmesi sonucunda sıcaklık dağılımları incelenmiştir. Çalışma kapsamında ameliyathanenin incelenmesinde iki farklı model (Model 1 ve Model 2) tasarlanmış ve tasarlanan bu modeller ANSYS Fluent programı ile simüle edilerek sayısal olarak analiz edilmiştir. Her bir model için x düzlemi boyunca beş ve z düzlemi boyunda üç farklı kesitte inceleme yapılmıştır. Model 1 için tavandan üfleme ve kenarlardan emme menfezleri ile hava emme şeklinde iklimlendirme yapılırken Model 2 için aseptizör cihazı ile üfleme ve emme yapılmıştır.

Analizler sonucunda elde edilen veriler incelendiğinde, Model 1 olarak tasarlanan tavandan üfleme, kenarlardan emme menfezleri ile hava emilen modelde incelenen kesitlerden ameliyat lambalarının cerrahi alan üzerinde konumlandırılması sonucu ölü kış bölgelerinin oluştuğu görülmüştür. Yine benzer şekilde monitör, cerrahi alet masası, koter vb. cihazlar tavandan askılı olmadığı için hava sirkülasyonunun engellendiği ve ölü akış bölgelerinin oluştuğu görülmüş olup ameliyat salonu içindeki cihazların mümkünse tavandan askılı olmasının uygun olacağı kanaatine varılmıştır. Bu modelde incelenen kesitlerde salondaki sıcaklık değerlerinin personeli ve hastayı rahatsız edici değerler olmadığı görülmüsşür.

Model 2 olarak tasarlanan aseptizör cihazı ile iklimlendirme yapılan modelde incelenen kesitlerde yüksek hava akış hızı nedeniyle ameliyathane personelinin konforsuzluk yaşadığı, cerrahi alan üzerinde laminer akışın sağlanamaması nedeniyle cerrahi alan enfeksiyonu gelişiminin mümkün olabileceği görülmüştür. Bu modelde de model 1'e benzer şekilde monitör, cerrahi alet masası, koter vb. cihazlar tavandan askılı olmadığı için hava sirkülasyonunun engellendiği ve ölü akış bölgelerinin oluştuğu görülmüştür. Ölü akış bölgelerinin oluşumuna aseptizör cihazının yerinin, üfleme menfezleri ve emme menfezlerinin konumunun neden olduğu düşünülmektedir. Aseptizör cihazı ameliyathane salonu içerisinde yer aldığı için filtrelerinin bakımı ve değiştirilmesi esnasında filtrelerdeki partiküllerin salona dökülmesi sonucu ameliyathanede enfeksiyon oluşma riski mevcuttur. Ayrıca aseptizör cihazı içerisinde 
emme girişinde emilen havanın nemini almaya yönelik bir düzenek olmadığından, aseptizör içerisindeki havanın yoğuşması ve bunun neticesinde cihaz içinde nem oluşumu nedeniyle enfeksiyon üreme riski bulunduğu görülmüştür.

Çalışmanın sonuçları incelendiğinde, standartlara ve literatürdeki çalışmaların sonuçlarına uygun olarak ameliyathanelerde en uygun havalandırma tekniğinin bu çalışmada Model 1 olarak tanımlanan tavandan üfleme menfezleri vasıtasıyla iklimlendirme olduğu görülmüştür.

\section{Teşekkür}

Bu çalışma, Mustafa Kemal Üniversitesi Fen Bilimleri Enstitüsü bünyesinde ve Dr. Öğr. Üyesi Yıldız KOÇ danışmanlığında yapılmış olan "İklimlendirilen Bir Ameliyathane Salonundaki Hava Akışının Sayısal Analizi” başlıklı tezden üretilmiştir. Yazarlar, çalışma boyunca katkılarından dolayı Üniversite ve Enstitü yönetimine teşekkürü bir borç bilmektedirler.

\section{Kaynakça}

[1] Azizoğlu, F., Onat, B., Sönmez, B., \& Hapçıŏglu, S. B. (2018) Temiz Oda Standartına Göre Ameliyathane ve Yoğun Bakımların Değerlendirilmesi. SDÜ Să̆llk Bilimleri Dergisi, 9(4), 26-31.

[2] Polat Y. (2011). Bir ameliyathane salonu iklimlendirilirken oluşan hava akımının sayısal analizi. Mustafa Kemal Üniversitesi, Yüksek Lisans Tezi Ocak-2011.

[3] Gezginci, E., \& Göktaş, S. Ameliyathanede iklimlendirme. Hemşirelik Bilimi Dergisi, 1(1), 100-109.

[4] Pittet, D., \& Ducel, G. (1994). Infectious risk factors related to operating rooms. Infection Control \& Hospital Epidemiology, 15(7), 456-462.

[5] Tosun MF, Karakuş C, Yağıı H, Baltacıŏglu H. (2015) Yoğun Bakım Ünitesinin Hijyenik İklimlendirme Hesabı ve Örnek Uygulama. TTMD Dergisi; 95: 30-36.

[6] Oğuzalp, E.H. (2011). Ameliyathanelerin steril yapılanmasında mimari detaylar ve bir şartname altyapı çalışması. Selçuk Üniversitesi Mühendislik, Bilim ve Teknoloji Dergisi, 26(1), 10-22.

[7] Chow, T. T., \& Yang, X. Y. (2004). Ventilation performance in operating theatres against airborne infection: review of research activities and practical guidance. Journal of Hospital Infection, 56(2), 85-92.

[8] Sağlı Bakanlığı (2018). Hastanelerde havalandırma ve kontrolü talimatı. (Erişim tarihi: 20.02.2019) https://dosyahastane.saglik.gov.tr/Eklenti/80537,ent107-hastanelerde-havalandirma-ve-kontrolu-talimatipdf.pdf?0

[9] Erciyes Üniversitesi. Hastanelerde Havalandırma Sistemi İlkeleri Raporu. (Erişim tarihi: 20.02.2019) http:/hastaneler.erciyes.edu.tr/Content/files/pdf/pdf/Hastane\%20havalandirmasi.pdf

[10] Peker T. (2007). Ameliyathanelerde standart, yönetmelik ve denetim boşluğu ve MMO yaklaşımı. VIII. Ulusal Tesisat Mühendisliği Kongresi. Ekim-2007, İzmir.

[11] Süngü A. (2007). Ameliyathane havalandırma sistemleri IVF ve genetik laboratuvar havalandırma sistemleri. 5. Ulusal Sterilizasyon Dezenfeksiyon Kongresi. Nisan-2007, Antalya.

[12] Taşdemir C. Hastane Ameliyathane ve Yoğun Bakımlarda Modüler Hijyen Klima Teknolojisi ve Enerji Maliyetleri. (Erişim tarihi: 20.02.2019) https://docplayer.biz.tr/7959664-Hastane-ameliyathane-ve-yogunbakimlarda-moduler-hijyen-klimateknolojisi-ve-enerji-maliyetleri.html

[13] AirTech (Erişim tarihi: 21.01.2019) http://www.air-tek.com.tr/laminer-akim-uniteleri-ve-hepa-filtre-kutulari/sayfa/2/40

[14] Memarzadeh, F., \& Manning, A. P. (2002). Comparison of operating room ventilation systems in the protection of the surgical site/Discussion. ASHRAE transactions, 108, 3. 